\title{
The role of physical education teacher creativity in mediating the influence of HRM practices and performance during the COVID-19 pandemic
}

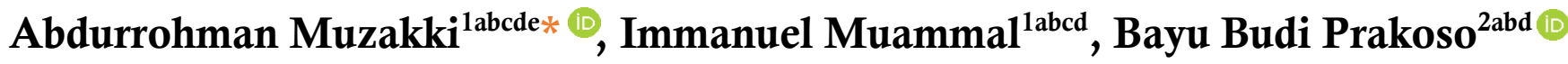 \\ Universitas Muhammadiyah Malang, Indonesia ${ }^{1}$ \\ Universitas Negeri Surabaya, Indonesia ${ }^{2}$
}

Received: 18 March 2021; Accepted 03 August 2021; Published 02 December 2021

Ed 2021; 6(3): 349-357

\begin{abstract}
This research was conducted with the aim of analyzing the position of teacher creativity in an effort to mediate the influence of the practice of Human Resource Management (HRM) which can be carried out by schools to improve teacher performance. This type of research is an explanatory research and also uses a quantitative approach. The variables in this research include several aspects such as the practice of implementing HRM, teacher creativity, and the performance of sports physical education teachers. This research was conducted by reaching a number of 102 sports physical education teachers consisting of several levels such as elementary, middle, and high schools in Malang City, Malang Regency and Batu City. Information can be obtained by distributing questionnaires either directly (offline) or online. The analysis of data information was carried out by researchers using SEM-PLS with the WARP PLS 7 application Meanwhile, the results of this research indicate the findings that the practice of HRM does not have a direct influence on the performance of sports physical education teachers with a significance value of 0.30 and the effect of HR Practice on The performance of sports teachers mediated by teacher creativity has a significance value of $<0.001$, which means that the teacher's creativity fully mediates the effect of HR practice on the performance of sports teachers.
\end{abstract}

Keywords: School management; MSDM practice; teacher creativity; teacher performance

https://doi.org/10.25299/sportarea. 2021.vol6(3).6570

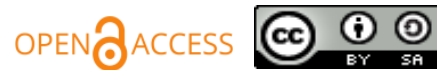

Copyright @ 2021 Abdurrohman Muzakki, Immanuel Muammal, Bayu Budi Prakoso

Corresponding Author: Abdurrohman Muzakki, Department of Primary Teacher Education, Faculty of Teacher Training and Education, Universitas Muhammadiyah Malang, Indonesia

Email: muzakki@umm.ac.id

How to Cite: Muzakki, A., Muammal, I., \& Prakoso, B. B. (2021). The role of physical education teacher creativity in mediating the influence of HRM practices and performance during the COVID-19 pandemic. Journal Sport Area, 6(3), 349-357. https://doi.org/10.25299/sportarea.2021.vol6(3).6570

Authors' Contribution: a - Study Design; b - Data Collection; c - Statistical Analysis; d - Manuscript Preparation; e - Funds Collection

\section{INTRODUCTION}

The current COVID-19 pandemic requires the government to urge every school to stop or to replace direct or offline learning and also replace it with online or online learning efforts (Rangiwai et al., 2020). In research Gumantan et al., (2021) he also explained that learning during the pandemic can already run effectively with online learning used for sports education students at the Indonesian Technocrat University. This pandemic also requires several countries to implement a policy called a lockdown and of course it has a very large effect on the prohibition of every sport activity, both indoor and outdoor (Varghese et al., 2020). 
Meanwhile, the implementation of sports activity programs can be tried independently or in groups. The thing is that many people think that sports activities are only easy to do and try outdoors. Therefore, it will be a problem in the current situation of this pandemic which is very limited in carrying out any outdoor activities due to the COVID-19 pandemic. Since January $30^{\text {th }}, 2020$, the World Health Organization has reported an international COVID-19 emergency (Sohrabi et al., 2020). The pattern of action and prevention of the spread of COVID-19 in the form of a lockdown or social restrictions on a large scale has an impact on the social life of citizens (Sohrabi et al., 2020). The real impact is on health, economy, and lifestyle which have been proven by the shrinking of sports activities which must be immediately addressed.

Teachers who have creativity and quality will lead to optimal learning and education processes (Qoni'ah et al., 2016). Education is a continuous learning process designed to provide good skills, understanding, and values so that they can develop themselves (Kopnina, 2020). The success of the learning world is influenced by various aspects such as teachers, facilities and infrastructure, as well as effective and conducive learning zones. The source of human energy in the world of learning is the teacher, who has a very significant position in the success of learning at school because a teacher helps the development of students. This shows that learning is truly a pioneer and a sign of national development. Indeed, it is emphasized that learning is a process that facilitates, education and the acquisition of theoretical and instant skills for people to use space efficiently for human development and growth. Learning is a process of bringing the desired change into human behavior (Azura \& Yudhyarta, 2020). Thus, the desired changes and behavior of people as a side effort of the knowledge and expertise acquired make them useful and acceptable human beings, and contribute to human development and growth.

The position of teachers in schools is very important in achieving educational success so that teachers are required to have a creative spirit in sharing educational procedures so that the learning outcomes of students become maximal and enjoyable (Anggoro, 2017). Moreover, physical education teachers are indeed required to teach their students to be fit and healthy so that students have an ideal BMI both now and in the future (Muzakki \& Saputra, 2020). Performance evaluation is an important process needed to measure organizational effectiveness. Performance measurement is a tool designed to measure individual success, attitude at work and contribution to the organization (Yildiz et al., 2013). In schools, good learning can be measured through teacher performance. How students can accept the method from the teacher is a measure of success. Therefore, teachers must have creativity in their learning methods without having to reduce the interest of students to keep learning.

Human resources are one of the main problems being faced by developing countries such as Indonesia in the goal of nation and state development. In connection with this, the management of human resources is very important for the creation of efficiency in an organization, society, or country which is currently known as Human Resource Management (HRM). Meanwhile, to increase the quality of the workforce is one of the most basic functions of education. A quality workforce requires physical, mental and spiritual health. Seeing this reality, physical education and sports become a single unit and seem to complement each other. The goals of these two educations are parallel, to provide personality training through physical education and to benefit society through recreational activities and play.

Physical education is the education of the whole personality. Through physical education, students are thought about how to use their bodies in the most effective and efficient way, how to move properly, become happy and ethical individuals and demonstrate positive mental and emotional development. Therefore, physical education and sports have an important place in the education system (Ramadhan et al., 2020). As a concept, physical education is expressed as a set of physical activities that aims to raise individuals as individuals who develop physically, spiritually, and physically which enable them to develop in a balanced manner (Suroto et al., 2017). For aspects that have an impact on the performance of both teachers and employees, it is the practice of (HR) in schools. Meanwhile, school performance is expected to increase with the seriousness of the implementation of HRM. The practice of HRM can also play a significant role in non-profit zones such as schools. A study also shows that the implementation of HRM can be correlated with an increase in performance in a school, and obviously there are teachers listed in it (Bryson et al., 2020). 
Performance appraisal is one of the processes especially needed to be able to measure the effectiveness of the organization. Performance appraisal is a tool that has been planned very well of course and can check and integrate the success, behavior, and attitudes of people in the workplace in detail and that takes into account the contribution of people to the success of the organization (Chu \& Zhang, 2018). Performance appraisal can be a determinant of whether the management of human resources (HR) is running properly and obviously it has been determined from an early age. The many descriptions that are lacking in performance appraisals are caused by a poor or unsystematic human resource management system (HRM). The key to the success of performance appraisal itself depends on human resource management (HRM) which is also a foundation for being able to work (Chu \& Zhang, 2018). Thus, HRM can be a force that can digest a system and study material for an organization in the school.

Learning plays a significant role in efforts to shape citizens and develop a nation (Sujana, 2019). The teacher is considered as a tool for seeing and hearing that is contained in every educational activity that wants to carve a memory from the emotions of the students. A teacher who is superior will want to succeed in simplifying every teaching process so that it is easily understood by students (Wardhana, 2020). Good and quality teachers are one aspect that can affect student education compared to other aspects such as class and financial dimensions (McFarlane, 2019). Therefore, teachers must equip themselves with special knowledge and skills to be able to complete each task and responsibility in each class. It becomes meaningful because of the challenges and complexity of teaching. These problems can be overcome if the teacher has great competence and can meet the standards as a teacher.

School performance will increase with seriousness (HRM). Furthermore, some applications of HRM that are considered valuable in non-profit areas may also be useful in schools and others may be less useful in schools. We create intensive use for implementation (HRM) correlates with substantial increases in performance in the workplace (Bryson et al., 2020). How can resource management (HRM) and creativity from resource management (HRM) itself be able to run optimally (Jyoti et al., 2020). For this reason, this study explores the role of resource management that will be felt by students with the mediating variable of creativity.

Creativity is considered to have a significant role in predicting innovative work attitudes and performance (Abdullah et al., 2019). The findings of this study indicate that there is a significant positive relationship between creativity and the performance of high school chemistry teachers (Sumiyati, 2018). Instructors can also influence employees' cognitive and work styles (skills relevant to creativity) based on role modeling, evaluation, and mastery experience (Knutson et al., 2018). Organizations can focus on screening prior to hiring employees based on task expertise and cognitive skills that are important for creativity. Training can be used to provide educational opportunities that enhance task domain skills (Kuncahyono et al., 2020). Offering training opportunities that can add to an individual's basic knowledge and/or creativity skills should assist employees in being more creative in their work (Truong et al., 2020). Research on training for creative problem solving has shown that it can help improve the thinking of different employees (Cascio et al., 2019).

Researchers have created a concept for the implementation of human resource management (HRM) resulting in the performance of employees through cognitive pathways where each employee is required to use more of one skill and another, as well as motivation, in which HRM practices increase employee motivation to be more successful at work. workplace (Olaisen \& Revang, 2017). In the research that has been done, it is stated that employee creativity has a substantial contribution to organizational innovation and competitive advantage (Zou et al., 2019). Furthermore, according to the interactionist perspective, creativity itself can be influenced by the interaction between various factors such as social such as socioemotional resources and contextual components such as management approaches (Jyoti et al., 2020). Workers or students in organizations that implement delegated management can experience a high degree of freedom (Tang et al., 2015), that inspires their creative behavior (Ekananta et al., 2018). Therefore, workers or students who have good organizational support want to show their skills in return through creativity.

In previous studies, there are several alibis as to why schools can benefit from the presence (HRM). Teachers play a major role in student achievement (Pozo-Rico \& Sandoval, 2020). The success of a school 
in an effort to meet every expectation that continues to grow in relation to the achievement of students most importantly depends on the competencies and efforts of all teachers. Teachers are people who must be willing to continue to strive to be professionals by incorporating new knowledge into daily learning practices, and HRM can be seen as a way for schools to offer their teachers opportunities for lasting professionalization. In conclusion, all over the world schools face difficulties to create enough highly qualified teachers (Knutson et al., 2018), And especially if the school can make it happen, many young teachers leave their jobs due to the fact that the work area doesn't live up to their expectations (Hämäläinen et al., 2021). The HRM system can help schools in their efforts to retain reasonably competent and motivated teachers (Loeb et al., 2012). Although there have been studies that have discussed the HRM system and also on teacher creativity, none has focused on researching HRM and the creativity of special physical education teachers during the COVID-19 pandemic, especially research that discusses also related to the performance of physical education teachers.

\section{METHOD}

This research uses a positivism research approach, while the method used is quantitative. The information used and analyzed in this research is qualitative information in the form of comments from respondents who report agreeing or disagreeing about the information which is then used as quantitative data. The type of research that has been used in this research is an explanatory research type. Explanatory research is research that explains the causal relationship between research variables and hypothesis testing (Gürbilek, 2013).

This research tries to identify the reflection of the influence of HRM practices on the performance of physical education and sports teachers by using teacher creativity mediation. This research information was obtained by filling out several questionnaires by respondents containing 12 questions using 5 Likert scales and trying them offline as well as online. Meanwhile, the distribution of questionnaires was implemented between the beginning of August and the end of October 2020. The grid of creativity instruments includes: (1) Fluidity, (2) Originality (Setiawan, 2017). As for the performance instrument uses a closed questionnaire so that respondents simply choose the answers that have been provided (Anita \& Damrah, 2020). Meanwhile, to measure the validity of this research, you can use the combined loadings and cross loadings output criteria, if the loading factor value is more than 0.40 and the p-value is significant $(<0.05)$ until the marker or item is declared valid. Evaluation of the reliability of this study is based on composite reliability and Cronbach's alpha. Both must be worth above 0.70 as a condition of reliability. The illustration method used is probability sampling consisting of 102 physical education teachers in the city of Malang and its surroundings. The types of respondents were 89 male physical education teachers and 13 female physical education teachers. Information analysis was tried using SEM-PLS and assisted by the WARP PLS 7 application.

\section{RESULTS AND DISCUSSION}

Table 1. Results of Validity Test of Research Instrument

\begin{tabular}{|c|c|c|c|c|}
\hline \multirow[b]{2}{*}{ Variables } & \multirow[b]{2}{*}{ Items } & \multicolumn{2}{|c|}{ Validity Test } & \multirow[b]{2}{*}{ Note } \\
\hline & & $\begin{array}{c}\text { Outer } \\
\text { Loading }\end{array}$ & $P$-Value & \\
\hline \multirow{6}{*}{ HRM Practices } & "X 1 Job Guarantee" & 0.089 & $<0,001$ & Valid \\
\hline & "X2 Training and Development" & 0.083 & $<0,001$ & Valid \\
\hline & "X 3 Performance Measurements" & 0.084 & $<0.001$ & Valid \\
\hline & "X4 Participation in Decision Making" & 0.083 & $<0,001$ & Valid \\
\hline & "X 5 Equality of Status" & 0.081 & $<0.001$ & Valid \\
\hline & "X 6 Rewards" & 0.081 & $<0,001$ & Valid \\
\hline \multirow{4}{*}{$\begin{array}{l}\text { Teachers' } \\
\text { Creativity }\end{array}$} & "Z 1 I try new ideas and methods" & 0.079 & $<0.001$ & Valid \\
\hline & "Z2 I look for new ideas and ways to" "solve problems" & 0.079 & $<0.001$ & Valid \\
\hline & "Z 3 I generate breakthrough ideas" & 0.081 & $<0,001$ & Valid \\
\hline & "Z 4 I am a good role model for creativity" & 0.086 & $<0,001$ & Valid \\
\hline
\end{tabular}




\begin{tabular}{|c|c|c|c|c|}
\hline \multirow[b]{2}{*}{ Variables } & \multirow[b]{2}{*}{ Items } & \multicolumn{2}{|c|}{ Validity Test } & \multirow[b]{2}{*}{ Note } \\
\hline & & $\begin{array}{c}\text { Outer } \\
\text { Loading }\end{array}$ & $P$-Value & \\
\hline \multirow{4}{*}{$\begin{array}{c}\text { Physical Education } \\
\text { Teachers' } \\
\text { Performance }\end{array}$} & "Y 1 task performance" & 0.081 & $<0,001$ & Valid \\
\hline & "Y2 contextual performance" & 0.080 & $<0,001$ & Valid \\
\hline & "Y3 adaptive performance" & 0.086 & $<0,001$ & Valid \\
\hline & "Y4 counter-productive work behavior" & 0.082 & $<0,001$ & Valid \\
\hline
\end{tabular}

Source : Processed Data, 2021

Based on table 1, it can be seen that the outer loading and $p<0.05$ and of course means that each variable marker is valid, and so it can be concluded that these indicators can be used to measure research variables.

Table 2. Results of Reliability of Research Instrument

\begin{tabular}{|c|c|c|c|c|}
\hline \multirow{2}{*}{ Variables } & & \multicolumn{2}{|c|}{ Realiability Test } & \multirow{2}{*}{ Note } \\
\hline & & Cronbach's Alpha & Composite Reliable & \\
\hline HRM Practices & & 0.977 & 0.981 & Reliable \\
\hline Teachers' Creativity & & 0.853 & 0.901 & Reliable \\
\hline $\begin{array}{l}\text { Physical Education } \\
\text { Performance }\end{array}$ & Teachers' & 0.913 & 0.933 & Reliable \\
\hline
\end{tabular}

Source : Processed Data, 2021

Table 2 shows that composite reliability filled with 3 variables has all scored above 0.70 and also with details as follows: for the practice results of HRD it is 0.981 , for the practice of creativity of physical education teachers it is 0.901 , while for the practice of performance physical education teacher is 0.933 . Then for the value of Cronbach's alpha which is also filled with 3 variables, it has also shown a value above 0.70 by obtaining the following details: for the practice results of HRM is 0.977 , while for the results of the creativity practice of of physical education teachers, it is 0.853 and for the results of the practice of performance by physical education teachers of 0.913 .

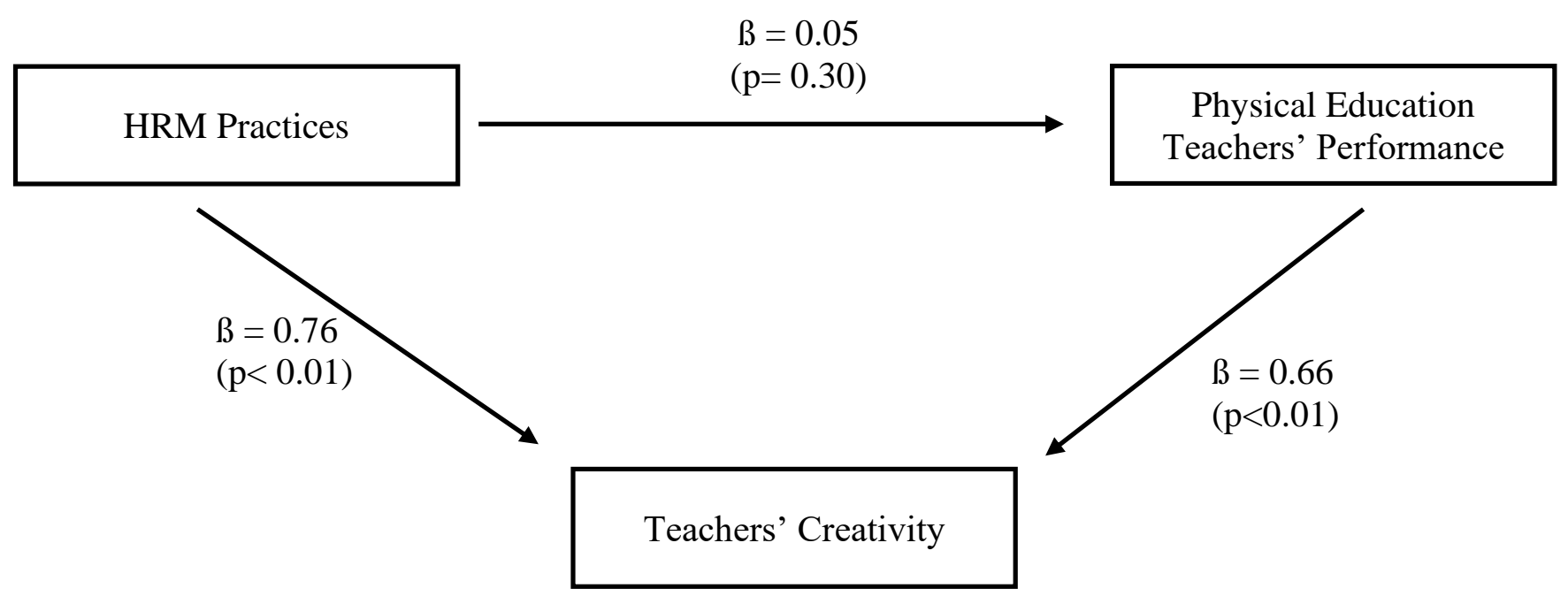

Figure 1. SEM-PLS Model of Direct Influence Testing

\section{The Effect of HRM Practices on the Performance of Physical Education Teachers}

The results of the research show that the practice bond of the application of HRM and the performance of physical education teachers has a negative effect $(0.05)$ with the result that the significance value of $p<0.05$ is obtained. Obviously, this value indicates that if the performance of physical education teachers is not affected by HRM practices, these results are in contrast to or refute the research attempted by Hashim et al., 
(2017) which shows when HRM practices affect the performance of a teacher in Pakistan. Furthermore, the results of this research certainly refute previous research which stated that HRM practices affect the positive outcomes of teacher performance in India (Jyoti et al., 2020). Thus, it can be concluded that the performance of physical education teachers in teaching cannot be significantly influenced by HRM practices.

\section{The Effect of HRM Practices on Teacher Creativity}

The results of Figure 1 show that the practice of HRM has a positive effect $(0.76)$ on teacher creativity with a significance value of $\mathrm{p}<0.05$. This shows that the practice of HRM has an effect of 0.76 on teacher creativity. This means that if the practice of HRM in schools is getting better, the creativity of teachers will be good too. From this it can be related that creativity is certainly very diverse to be defined because creativity is a multidimensional concept that has so many, as presented by experts to suggest the meaning of creativity (Turpin et al., 2015).

\section{The Effect of Teacher Creativity on Physical Education Teacher Performance}

The results of Figure 1 show that teacher creativity has a positive effect $(0.66)$ on the performance of physical education teachers by getting a significant result of $p<0.05$. This shows that teacher creativity has an effect of 0.66 on the performance of physical education teachers. Basically, creativity is the ability of an individual to create an idea, an idea to produce a work. The term creativity is very diverse to define because creativity is a multidimensional concept that so many experts advocate the meaning of creativity (Turpin et al., 2015), however, most experts interpret creativity as a person's ability to create something new, both in concepts and real works (Cheung, 2016). The results of previous studies reported that in today's world of globalization, creativity is an important element in development and it is the basic capital in building a better quality of human resources in a country (Bereczki \& Kárpáti, 2018). Thus, it can be concluded that creativity has a very positive impact on the performance of physical education teachers in teaching (Cheung, 2016).

The Role of Teacher Creativity with Teacher Performance in Mediating the Effect of HRM Practices on Teacher Performance in Physical Education

Table 3. SEM-PLS Results of Indirect Influence Testing

\begin{tabular}{lccc}
\multicolumn{1}{c}{ Variable Correlation } & Path Coeficients & P-Value & Note \\
\hline HRM Practices => Teachers' Performance => Physical & \multirow{2}{*}{0.38} & $<0.001$ & \multirow{2}{*}{ Full mediation } \\
Education Teachers' Performance & & & \\
\hline
\end{tabular}

From table 3, it can be seen that the influence of HRM practices on the performance of physical education teachers mediated by teacher creativity has a significance value of $p<0.05$ and from the relationship of the direct influence of HRM practices on the performance of physical education teachers, it is known that the relationship is not significant. This means that teacher creativity can mediate the influence of HRM practices on the performance of physical education teachers significantly (full mediation). Proven according to previous research according to Loeb et al., (2012) revealed that the HRM system can help schools in an effort to retain teachers who are competent enough and can continue to be motivated in teaching and learning activities. With this research, it can be concluded that the creativity of physical education teachers can significantly mediate the effect of HRM practices on the performance of physical education teachers.

\section{CONCLUSION}

Based on the results of research on the position of teacher creativity in its efforts to mediate the influence of HRM practices which resulted in the performance of physical education teachers during the COVID-19 pandemic, it can be concluded that this HRM practice does not affect the performance of physical education teachers, on the contrary creativity fully functions as a mediator in an influence of HRM practices on the performance of physical education teachers. From the descriptions that have been presented, it can be 
recognized that during the COVID-19 pandemic, the practice of HRM which has been accompanied by the creativity of teachers will improve the performance of teachers. This research was carried out during the COVID-19 pandemic, obviously there is a possibility that the results will be different if it is tried during normal times or other than COVID-19. This research has limitations where the sample and location are only limited to the Malang Raya area, therefore it is hoped that further researchers will be able to develop it to improve research results by using improved analysis.

\section{ACKNOWLEDGEMENT}

Thank you to those who have contributed to this research, especially to Sports Physical Education teachers consisting of several levels such as elementary, middle, and high schools in Malang City, Malang Regency and Batu City.

\section{CONFLICT OF INTEREST}

All authors declare there is no conflict of interest in this study. Further research needs to be carried out on a broader and comprehensive scale such as at the National level.

\section{REFERENCES}

Abdullah, N. H., Wahab, E., \& Shamsuddin, A. (2019). Creative self-efficacy, innovative work behaviour and job performance among selected manufacturing employees. Journal of Social Sciences Research. 11(1), 99-108. https://doi.org/10.32861/jssr.52.291.297

Anita, S., \& Damrah. (2020). Kinerja Guru Pendidikan Jasmani Olahraga dan Kesehatan di Masa New Normal Covid-19. Jurnal Kesehatan Medika Saintika. 1(2), 90-101. http://dx.doi.org/10.30633/jkms.v11i1.859

Anggoro, S. (2017). Keberhasilan Pendidikan Finlandia. Universitas Muhammadiyah Purwokerto.

Azura, N., \& Yudhyarta, D. Y. (2020). Pengaruh Pendidikan Moral Terhadap Prilaku Siswa Pada Mata Pelajaran Pendidikan Kewarganegaraan di Madrasah Ibtidaiyah Negeri 1 Indragiri Hilir. ASATIZA: Jurnal Pendidikan. 19(2), 47-56. https://doi.org/10.46963/asatiza.v1i2.79

Bereczki, E. O., \& Kárpáti, A. (2018). Teachers' beliefs about creativity and its nurture: A systematic review of the recent research literature. In Educational Research Review. 19(3), 102-111. https://doi.org/10.1016/j.edurev.2017.10.003

Bryson, A., Stokes, L., \& Wilkinson, D. (2020). Can HRM improve schools' performance? Labour: Review of Labour Economics and Industrial Relations. 34(4), 427-440. https://doi.org/10.1111/labr.12178

Cascio, C. J., Moore, D., \& McGlone, F. (2019). Social touch and human development. Developmental Cognitive Neuroscience. 35(4), 5-11. https://doi.org/10.1016/j.den.2018.04.009

Cheung, R. H. P. (2016). The challenge of developing creativity in a Chinese context: the effectiveness of adapting Western creative pedagogy to inform creative practice. Pedagogy, Culture and Society. 24(1), 1-20. https://doi.org/10.1080/14681366.2015.1087419

Chu, T. L., \& Zhang, T. (2018). Motivational processes in Sport Education programs among high school students: A systematic review. European Physical Education Review, 24(3), 372-394. https://doi.org/10.1177/1356336X17751231

Ekananta, A., Maarif, S., Affandi, J., \& Sukmawati, A. (2018). Analisis situasional kinerja dan kompetensi profesi manajemen sumber daya manusia di indonesia. Jurnal Manajemen. 10(1), 67-79 https://doi.org/10.29264/jmmn.v10i1.2500

Gumantan, A., Nugroho, R. A., \& Yuliandra, R. (2021). Learning During the Covid-19 Pandemic: Analysis of E-Learning on Sports Education Students. Journal Sport Area. 6(1), 51-58. 
https://doi.org/10.25299/sportarea.2021.vol6(1).5397

Gürbilek, N. (2013). Cooper dan Schindler. Journal of Chemical Information and Modeling. 6(2), 210-126. https://doi.org/10.1063/5.0038527

Hämäläinen, R., Nissinen, K., Mannonen, J., Lämsä, J., Leino, K., \& Taajamo, M. (2021). Understanding teaching professionals' digital competence: What do PIAAC and TALIS reveal about technologyrelated skills, attitudes, and knowledge? Computers in Human Behavior. 117(4), 102-112. https://doi.org/10.1016/j.chb.2020.106672

Hashim, M., Rafi, S., Sheheryar, S., Kazmi, A., Ullah, M., Mui, D., \& Kee, H. (2017). Impact of Human Resource Practices on Perceived Performance: a Study of Teaching Faculty in Private Universities of Peshawar, Pakistan. City University Research Journal Special Issue: AIC, Malaysia PP. 4(2), 120-129. https://doi.org/10.1080/00958964.2019.1710444

Jyoti, J., Sharma, P., \& Rani, A. (2020). Assessing the impact of human resource management practices on teachers' performance through HR analytics. In Sustainable Business Practices for Rural Development: The Role of Intellectual Capital. 1(2), 31-55. https://doi.org/10.1007/978-981-13-9298-6_11

Knutson, D., Koch, J. M., Sneed, J., \& Lee, A. (2018). The Emotional and Psychological Experiences of Drag Performers: A Qualitative Study. Journal of LGBT Issues in Counseling. 12(1), 32-50. https://doi.org/10.1080/15538605.2018.1421114

Kopnina, H. (2020). Education for the future? Critical evaluation of education for sustainable development goals. Journal of Environmental Education. 5(1),1-12. https://doi.org/10.1080/00958964.2019.1710444

Kuncahyono, K., Suwandayani, B. I., \& Muzakki, A. (2020). Aplikasi E-Test “That Quiz" sebagai Digitalisasi Keterampilan Pembelajaran Abad 21 di Sekolah Indonesia Bangkok. Lectura: Jurnal Pendidikan. 11(2), 153-166. https://doi.org/10.31849/lectura.v11i2.4687

Loeb, S., Kalogrides, D., \& Béteille, T. (2012). Effective schools: Teacher hiring, assignment, development, and retention. Education Finance and Policy. 7(3), 269-304. https://doi.org/10.1162/EDFP_a_00068

McFarlane, A. E. (2019). Devices and desires: Competing visions of a good education in the digital age. British Journal of Educational Technology. 50(3), 1125-1136. https://doi.org/10.1111/bjet.12764

Muzakki, A., \& Saputra, S. Y. (2020). Hubungan Antara Body Mass Index dengan Physical Fitness Pada Mahasiswa PGSD. Jurnal Pemikiran dan Pengembangan Sekolah Dasar (JP2SD). 8(1), 88-98. https://doi.org/10.22219/jp2sd.v8i1.12414

Olaisen, J., \& Revang, O. (2017). Working smarter and greener: Collaborative knowledge sharing in virtual global project teams. International Journal of Information Management. 37(1), 1441-1448. https://doi.org/10.1016/j.ijinfomgt.2016.10.002

Pozo-Rico, T., \& Sandoval, I. (2020). Can Academic Achievement in Primary School Students Be Improved Through Teacher Training on Emotional Intelligence as a Key Academic Competency? Frontiers in Psychology. 7(2), 77-90. https://doi.org/10.3389/fpsyg.2019.02976

Qoni'ah, N., Irawan, D., \& Purwanti, E. (2016). Penerapan Manajemen Sumber Daya Manusia (Msdm) Dalam Meningkatkan Kinerja Guru di SMK Yasmida Ambarawa Kabupaten Pringsewu. STTI Pringsewu. 2(2), 46-53.

Ramadhan, M. G., Ma'mun, A., \& Mahendra, A. (2020). Implementasi Kebijakan Olahraga Pendidikan sebagai Upaya Pembangunan Melalui Olahraga Berdasarkan Undang-Undang Sistem Keolahragaan Nasional. Jurnal Terapan Ilmu Keolahragaan. 5(1), 22-34. https://doi.org/10.17509/jtikor.v5i1.23824

Rangiwai, B., Simati-Kumar Chand, B., \& Mataroa, R. (2020). The impacts of COVID-19 on the 2020 cohort of the Master of Applied Indigenous Knowledge programme at Te Wānanga o Aotearoa in Māngere. Te Kaharoa. 15(1), 34-43. https://doi.org/10.24135/tekaharoa.v15i1.301 
Setiawan, E. (2017). Development Creativity Students Through the Application of Problem Based Learning Model in Physical Education in Reviewed of Adversity Quotient. Jurnal Pendidikan Jasmani dan Olahraga. 2(2) 84-94. https://doi.org/10.17509/jpjo.v2i2.8173

Sohrabi, C., Alsafi, Z., O’Neill, N., Khan, M., Kerwan, A., Al-Jabir, A., Iosifidis, C., \& Agha, R. (2020). World Health Organization declares global emergency: A review of the 2019 novel coronavirus (COVID-19). In International Journal of Surgery. 76(2), 66-76. https://doi.org/10.1016/j.ijsu.2020.02.034

Sujana, I. W. C. (2019). Fungsi dan Tujuan Pendidikan Indonesia. Adi Widya: Jurnal Pendidikan Dasar. 4(1), 29-39. https://doi.org/10.25078/aw.v4i1.927

Sumiyati, S. (2018). Hubungan Antara Kreatifitas Dengan Kinerja Guru Kimia SMA di Jabodetabek. Jurnal Dinamika Pendidikan. 11(1), 58-80. https://doi.org/10.33541/jdp.v11i1.797

Suroto, Khory, F. D., Dinata, V. C., \& Priambodo, A. (2017). Core Competency Measurement Model for Prospective Physical Education Teacher. IOP Conference Series: Materials Science and Engineering. 1(1), 1-7. https://doi.org/10.1088/1757-899X/180/1/012181

Tang, G., Wei, L. Q., Snape, E., \& Ng, Y. C. (2015). How effective human resource management promotes corporate entrepreneurship: evidence from China. International Journal of Human Resource Management. 26(12), 66-78. https://doi.org/10.1080/09585192.2014.953973

Truong, L. K., Mosewich, A. D., Holt, C. J., Le, C. Y., Miciak, M., \& Whittaker, J. L. (2020). Psychological, social and contextual factors across recovery stages following a sport-related knee injury: A scoping review. In British Journal of Sports Medicine. 54(19), 1149-1156. https://doi.org/10.1136/bjsports-2019-101206

Turpin, M., Matthee, M., \& Kruger, A. (2015). The teaching of creativity in information systems programmes at South African higher education institutions. African Journal of Research in Mathematics, Science and Technology Education. 19(3), 1-11. https://doi.org/10.1080/10288457.2015.1104838

Varghese, G., John, R., Manesh, A., Karthik, R., \& Abraham, O. (2020). Clinical management of COVID19. In Indian Journal of Medical Research. 151(5), 401-410. https://doi.org/10.4103/ijmr.IJMR_957_20

Wardhana, W. S. (2020). Strategi Pengembangan Kompetensi Guru Secara Mandiri di Era Literasi Digital. Prosiding Seminar Nasional Bahasa dan Sastra Indonesia (SENASBASA). 4(1), 11-23.

Yildiz, I. B., von Kriegstein, K., \& Kiebel, S. J. (2013). From Birdsong to Human Speech Recognition: Bayesian Inference on a Hierarchy of Nonlinear Dynamical Systems. PLoS Computational Biology. 9(9), 21-34. https://doi.org/10.1371/journal.pcbi.1003219

Zou, W., Lo, D., Kochhar, P. S., Le, X.-B. D., Xia, X., Feng, Y., Chen, Z., \& Xu, B. (2019). Smart Contract Development: Challenges and Opportunities. IEEE Transactions on Software Engineering. 5(4) 46-57. https://doi.org/10.1109/tse.2019.2942301 